\title{
Privatization of Power Sector in Nigeria: An Evaluation of Ibadan and Ikeja Electricity Distribution Companies Performance (2005-2018)
}

\section{Samuel Sunday Idowu , Jide Ibietan \& Ayo Olukotun}

To cite this article: Samuel Sunday Idowu, Jide Ibietan \& Ayo Olukotun (2020) Privatization of Power Sector in Nigeria: An Evaluation of Ibadan and Ikeja Electricity Distribution Companies Performance (2005-2018), International Journal of Public Administration, 43:16, 1413-1420, DOI: 10.1080/01900692.2019.1672183

To link to this article: https://doi.org/10.1080/01900692.2019.1672183

Published online: 01 Oct 2019.

Submit your article to this journal $\sqsubset$

Џ Article views: 91

Q View related articles $\sqsubset$

View Crossmark data $־$

Citing articles: 1 View citing articles \ulcorner 


\title{
Privatization of Power Sector in Nigeria: An Evaluation of Ibadan and Ikeja Electricity Distribution Companies Performance (2005-2018)
}

\author{
Samuel Sunday Idowu ${ }^{\mathrm{a}}$, Jide Ibietan ${ }^{\mathrm{a}}$, and Ayo Olukotun ${ }^{\mathrm{b}}$

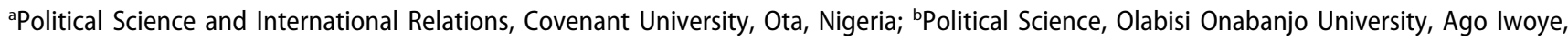 \\ Nigeria
}

\begin{abstract}
The challenge of stable electricity supply in Nigeria with its harrowing effects on socio-economic development accounted largely for government decision for privatization of the power sector. However, the extent to which this purpose has been achieved requires investigation, which necessitates this study. Survey research design was adopted, with questionnaire administered on both residential and commercial customers of Ibadan and Ikeja electricity Distribution companies selected as focus for the study. Multiple regression statistics was used for data analysis. The result shows that both distribution companies (DISCOs) have brought no significant improvement to electricity supply going by the quality, billing, coverage, metering, load shedding, and response to customers' indicators. Thus we recommend that DISCOs should source for fund from the capital market in order engender customer satisfaction, inject fund for replacement or upgrade of dilapidated power equipments, provision of meters, especially, prepaid type while government make the business environment convenient for healthy competition and regulation.
\end{abstract}

\section{KEYWORDS}

Privatization; power sector; distribution companies; performance

\section{Introduction}

\section{Background to the study}

United Nations Conference on Trade and Development (UNCTAD) (2009, p. 59) asserts that "The Nigerian electricity power system, which has been run since 1972 by vertically integrated state-owned monopoly National Electric Power Authority (NEPA), is chronically dilapidated with respect to infrastructure, commercial standards and customer service" This aptly captures the dire state of the country's power sector, thus necessitating government reform programs in which privatization is Kernel amongst other measures.

Omoleke (2011) specifically documents NEPA challenges, before it was structurally transformed into Power Holding Company (PHCN) for privatization, as that of insufficient power generation, poor access to infrastructure, low connection rate, inefficient capacity utilization, and inadequate transmission and distribution facilities among others. The depressive impact of poor electricity supply on social wellbeing and economic growth underscores the criticism of NEPA's on its abysmal performance and increasing demands from customers and stakeholders, including international organizations, such as, World Bank, International Monetary Fund, for its privatization. Additionally at the domestic level, most of the commissions instituted on the review of public utilities service delivery by the government strongly recommended privatization or commercialization of public enterprises, especially the Onosode commission (Ibietan, 2013). As a result, and, in response to NEPA's performance, privatization of the sector was considered by government as an option.

Firstly, the Technical Committee on Privatisation and Commercialization (TCPC) established by the government in pursuit of the privatization policy partially commercialized NEPA (Zayyad, 1992). It was the first window used to introduce NEPA to business orientation management, which according to Abdul (1992), brought improvement on the facilities, staff welfare and revenue collection. But, it appears this fell short of customers' expectations making it to undergo a review of its management, especially ownership and control. Thus, in 1999, NEPA was not only slated for privatization (Adelaja, 2007), but also Power Sector Reform Bill (PSRB) was signed into law intends to enable private sector involvement in power generation, transmission and distribution. Furthermore, the Bill empowered Power Holding Company of Nigeria (PHCN) as successor to NEPA and unbundled it into 18 companies comprising of six generation companies (GENCOs), one transmission company (TCN) and 11

CONTACT Samuel Sunday Idowu sunsamd@yahoo.com $@$ Political Science and International Relations, Covenant University, 234 Km. 10 Ota-Idiroko Road, Ota, Ogun State, Nigeria

(c) 2019 Taylor \& Francis Group, LLC 
distribution companies (DISCOs) with National Electricity Regulatory Commission (NERC) as regulatory institution (Onagoruwa, 2011).

In 2013, DISCOs and GENCOs were privatized while TCN was place under management contract agreement (Enoche, Egware, \& Eyakanor, 2015). By these structural changes, PHCN existence ended, NERC fully assumed regulatory roles, and the sector became operational under a liberalized environment and private sector driven at the same time. Expectedly, the public sector bureaucratic bottleneck, managerial interference, and other constraints hampering power sector efficient performance started receiving attention. However, empirical research to ascertain the Nigeria power sector postprivatization performance assessment is lacking in the literature but scanty textual analysis. Thus, this work, using Ibadan and Ikeja DISCOs as focus, examines whether Nigeria's power sector privatization has brought about improved performance of DISCOs in the postprivatization era. The work is divided into seven sections. Following this introduction is the theoretical framework while empirical framework comes after. Method of study takes the fourth section while data presentation and analysis follows as the fifth. Afterward, discussion of findings and conclusion and recommendations account for the sixth and seventh sections respectively.

\section{Theoretical framework}

This work utilizes the theory of privatization as appropriate framework for its analysis. Privatization as a concept "has been prominent in international economic and political circles since 1970s" (Omoleke and Adeopo, 2005, p 69). Its origin is traced to United Kingdom (UK) as forerunner in 1970s but became a consuming economic passion under Margret Thatcher's last two terms (Clarke \& Chisto, 1993). Put differently, privatization gained prominence as a theory out of UK's adoption and application for economic reformation. Nevertheless, it derives its thrust from neoliberal political-economic orientation. As noted by Muogbo (2013), it is anchored on the benefits of market economy system, especially efficient service, effectiveness and productivity alongside deregulation or liberalization of operating environment. However, to what extent can free market economy bring about efficient private delivery of reckonable performance in every economy without government intervention in the system is a pertinent question that privatization advocates have not provided satisfactory answers to, especially, the extent and limit of public sector involvement.
Nevertheless, Urgorji (1995) asserts that privatization is an acceptable policy states' political economy. This suggests that it has accounted for its global embrace in economic reforms beginning from mid1980s in some developing economies like Nigeria. Hence, its application to the power sector reforms program by Nigeria government. The anticipated deliverables, more importantly, improved performance of public utilities, to a large extent, informed government's efforts in adopting privatization of the sector with high optimism that NEPA's inefficiency, unprofitable management system, and other shortcomings would become historical narratives. The implication is that new experience, according to Gujral (2013) of reliable power supply, tariffs, efficiency of service, response to customers' needs, used in measuring electricity sector performance, and others, such as metering and extensive coverage areas, would be entrenched. As such, populace expectation of better electricity experience is heighten with believe of its corresponding headlong effect on national socio-economic life.

But, Aluko's (n.d. cited in Muogbo, 2013) averment that private sector inherent efficiency from Nigeria's experience is questionable, because their profit emanated from inflated contracts, patronage and corruption rather than efficient operation and productivity. In this sense, the efficiency performance thesis of privatization seems doubtful in the Nigeria's context, considering her unpredictable political environment that appears to entangle liberal business operations. Can one isolate private operators in the country's power sector from this unwholesome indulgence? It seems impossible because of the shared business environment. Therefore, postprivatization performance of IBEDC and IKEDC in such situations cannot be assumed with certainty and, this, requires investigation.

\section{Empirical review of cross-national postprivatization performance}

This section reviews empirical findings of researches on postprivatization performance of both developed and emerging economies with a view to providing insight for this study.

In the study assessing postprivatization of power sector in India by Zafar (2015) titled "Best Practices India Power Sector Restructuring Study: Short Review of Privatisation in Power Sector," the findings of Orissa state Electricity Board Privatisation in 1996, which was the ninth largest state in India, revealed that electrified territory increased by 13 percent, brought cash flow for government and also increased Gross Domestic Product (GDP) by 12\%on annual basis (Zafar, 2017: 9). It implies 
that government revenue was boosted and more citizens are connected to electricity power as dividends of postprivatization within the state showed positive impact on GDP. Nevertheless, pricing and quality of services among other indices were not included in the research.

The work of Soukaina and Amal (2015) on United Kingdom (UK) titled "The British Privatisation of Electricity Network Industry: The effect of the Electricity Reform on Domestic Electricity Price in the United Kingdom," shows that the price of electricity was not influenced by privatization significantly and responded to coal and natural gas prices that are exogenous factors as well. While these findings were arrived at from the correlation analysis of domestic retail price of electricity and fuel price, it does not consider the country's preprivatization pricing that seems relatively stable when compared with developing countries like Nigeria characterized by tariff subsidy from government and poor regulatory environment.

In the assessment of Cameroon electricity sector reform by Pincus (2014) titled "Transparency in the Dark-An assessment of the Cameroon Electricity Sector Reform", findings show that private sector investment growing the economy was partly achieved while the goal of improving quality of services was not achieved but worsened. Also, increase in access to electricity was attained but competitive pricing was not achieved. Cameroon postprivatization performance, going by pricing, was a failure but more customers are connected to electricity power. Hence its impact on the socio-economy could not have been fully attained since the price does not promote low tariff or production cost.

Nepal and Foster (2016) study of Australia postprivatization power sector privatization experience titled "Electricity Networks Privatisation in Australia: An Overview of the Debate" findings of the comparative study of privately owned and state-owned companies disclosed that private companies tariff is not worse off; they reduced network costs and improved quality of electricity supply and investment without price increase when compared to state-owned companies. In sum, the findings position privately owned firms better in terms of performance than public enterprises judging by fair pricing and quality of electricity supply.

The study of Hashim (2017) on Iraq titled "An assessment of Electricity sector Reform in Iraq" corroborated that of Australia positive gains as it revealed that privatization of the sector brought about a reduction in electricity consumption, curbed energy waste and as well reduced collection fees. Iraq's experience showcases consumers' prudent usage of power as part of postprivatization benefits, aside lesser consumption cost to the DISCOs.
From the empirical review, while findings show somewhat positive benefits in most countries, it appears there exist no single study that comprehensively carried out a postprivatization study using the key variables of quality of electricity supply, pricing or billing, coverage, metering, Load shedding and Responsiveness to customers' needs by DISCOs.

\section{Method of study}

This research adopts survey research method and elicits data through Likert 4-type questionnaire from residential and commercial customers of IBEDC and IKEDC.

\section{Population of the study}

Residential and commercial customers of IBEDC and IKEDC constitute the population of this study. The industrial customers are excluded because a sizable number of them depend less on national grid for power supply. IBEDC has 1,595.000 (IBEDC prospectus, 2017) while IKEDC (IKEDC prospectus, 2017) has 690,000 total number of both residential and commercial customers respectively totaling 2,285,000.

\section{Sample and sampling method}

The Krejcie and Morgan (1970) sample size formula was used to determine the sample for this study. This is shown in Table 1 . The sample size recommended by Table 1 for IBEDC and IKEDC is 382 and 384 respectively and both totaled 771 . However, because of the large number of IBEDC customers, its sample size was increased to 499 that is by $30 \%$ as suggested by Israel (2013). Thus, the total sample size for the study is 881

Table 1. Table for determining sample size of known population.

\begin{tabular}{cccccccccc}
\hline $\mathrm{N}$ & $\mathrm{S}$ & $\mathrm{N}$ & $\mathrm{S}$ & $\mathrm{N}$ & $\mathrm{S}$ & $\mathrm{N}$ & $\mathrm{S}$ & $\mathrm{N}$ & $\mathrm{S}$ \\
\hline 10 & 10 & 100 & 80 & 280 & 162 & 800 & 260 & 2,800 & 338 \\
15 & 14 & 110 & 86 & 290 & 165 & 850 & 265 & 3,000 & 341 \\
20 & 19 & 120 & 92 & 300 & 169 & 900 & 269 & 3,500 & 346 \\
25 & 24 & 130 & 97 & 320 & 175 & 950 & 274 & 4,000 & 351 \\
30 & 28 & 140 & 103 & 340 & 181 & 1,000 & 278 & 4,500 & 354 \\
35 & 32 & 150 & 108 & 360 & 186 & 1,100 & 285 & 5,000 & 357 \\
40 & 36 & 160 & 113 & 380 & 191 & 1,200 & 291 & 6,000 & 361 \\
45 & 40 & 170 & 118 & 400 & 196 & 1,300 & 297 & 7,000 & 364 \\
50 & 44 & 180 & 123 & 420 & 201 & 1,400 & 302 & 8,000 & 367 \\
55 & 48 & 190 & 127 & 440 & 205 & 1,500 & 306 & 9,000 & 368 \\
60 & 52 & 200 & 132 & 460 & 210 & 1,600 & 310 & 10,000 & 370 \\
65 & 56 & 210 & 136 & 480 & 214 & 1,700 & 313 & 15,000 & 375 \\
70 & 59 & 220 & 140 & 500 & 217 & 1,800 & 317 & 20,000 & 377 \\
75 & 63 & 230 & 144 & 550 & 226 & 1,900 & 320 & 30,000 & 379 \\
80 & 66 & 240 & 148 & 600 & 234 & 2,000 & 322 & 40,000 & 380 \\
85 & 70 & 250 & 152 & 650 & 242 & 2,200 & 327 & 50,000 & 381 \\
90 & 73 & 260 & 155 & 700 & 248 & 2,400 & 331 & 75,000 & 382 \\
95 & 76 & 270 & 159 & 750 & 254 & 2,600 & 335 & $1,000,000$ & 384 \\
\hline
\end{tabular}

Note: $\mathrm{N}$ is Population Size; $\mathrm{S}$ is Sample Size

Source: Krejcie \& Morgan 1970 
Table 2. Internal consistency reliability result.

\begin{tabular}{lcc}
\hline Variables & Cronbach's alpha & Items \\
\hline Electricity supply & 0.711 & 2 \\
Pricing/Billing & 0.852 & 2 \\
Coverage & 0.951 & 2 \\
Metering & 0.801 & 2 \\
Load shedding & 0.791 & 2 \\
Response to customers & 0.773 & 2 \\
Average & $\mathbf{0 . 8 1 3}$ & $\mathbf{6}$ \\
\hline
\end{tabular}

Source: SPSS Output Result.

enhancing good representativeness of the population. Also, multi-stage sampling technique was used for this study. At first stage, stratified sampling was adopted to classify the study population into five regions-Ibadan, Oyo, Kwara, Ogun an Osun for IBEDC and business hubs into Abule-Egba, Akowonjo, Ikeja, Ikorodu, Oshodi and Somolu-for IKEDC. Thereafter, Simple random sampling was used at second stage in selecting residential and commercial customers within both companies franchise areas. Questionnaire was administered on the selected areas.

\section{Validity and reliability of instrument}

Firstly, logical validity was in ascertaining research instrument. To this effect, experts were drawn from the senior faculty members of the Department of Political Science and International Relations to Covenant University Ota to validate the questionnaire. Cronbach Alpha test, which exceeded 0.7, that is, 0.813 as shown in Table 2, was used to confirm the reliability of the instrument

\section{Method of data analysis}

Both descriptive and multiple regression inferential statistical analysis were used as analytical tools for this study. The demographic and respondents data to questionnaire were presented in tables and descriptively analyzed while regression was used to predict the strength of relationship and test the research hypothesis. Noteworthy, IBM SPSS Modellers version 23 was employed for the statistical analysis.

\section{Data presentation and discussion}

This section presents biographical and responses of respondents data to questions posed. Afterward, the data was analyzed which provide premises for the research conclusion and recommendations.

\section{Descriptive statistics on the critical parameters for postprivatization performance of IBEDC and IKEDC}

Table 3 shows descriptive statistics of responses to postprivatization indicators of electricity supply, pricing, coverage, metering, load shedding, and responsiveness to customers' needs. These are critical success factors that largely determine the extent of DISCOs performance. While customers either agree or disagree with the questions, it is instructive that most of the items are disagreed with are to varying degrees by most respondents with an overall mean of 1.92 (SD = 0.55). Similarly, from the performance column, it can be inferred that respondents disagreed that they are satisfied with the service of the distribution Companies in their communities. Implicitly, DISCOs performance, judging by the indices, fell short of customers' satisfaction with supply, coverage and load shedding indicating higher abysmally poor performance level. Hence, postprivatization performance fell short of being described as successful making inefficiency prevalent in the sector that suggest that DISCOs lacked required technical, managerial and financial capacity to drive electricity distributions within their franchise areas.

\section{Hypothesis testing}

\section{Research hypothesis}

The research hypothesis is stated below:

$\mathrm{H}_{\mathrm{o}}$ critical parameters have no significant impact on the postprivatization performance of IBEDC and IKEDC in Nigeria

$\mathrm{H}_{1}$ critical parameters have significant impact on the postprivatization performance of IBEDC and IKEDC.

Interpretation of result. Table 4 shows the extent to which the variance in the dependent variable of performance outcome is explained by the independent variable (critical parameters or indices measure). The adjusted R-squared that identified the percentage of variance in the dependent variable, explained by the independent variable shows 202 (that is $20.2 \%$ ) variability of the independent variable that is, indices measures of response to customers load shedding, electricity supply, pricing, metering and coverage. The standard error of the estimate indicates 391012 that signified error term. The Durbin Watson result at 1.719 is within recommended range of $1.5-2.5$ validating the result.

Table 5 appraises the statistical significance of the six measures of privatization measures of power sector. ANOVA tests the null hypothesis that multiple $\mathrm{R}$ in the population equals O. Decision Rule: Reject the Null hypothesis, when the significance value is below 0.05 . Do not reject hypothesis, when significance value is greater than 0.05 . 


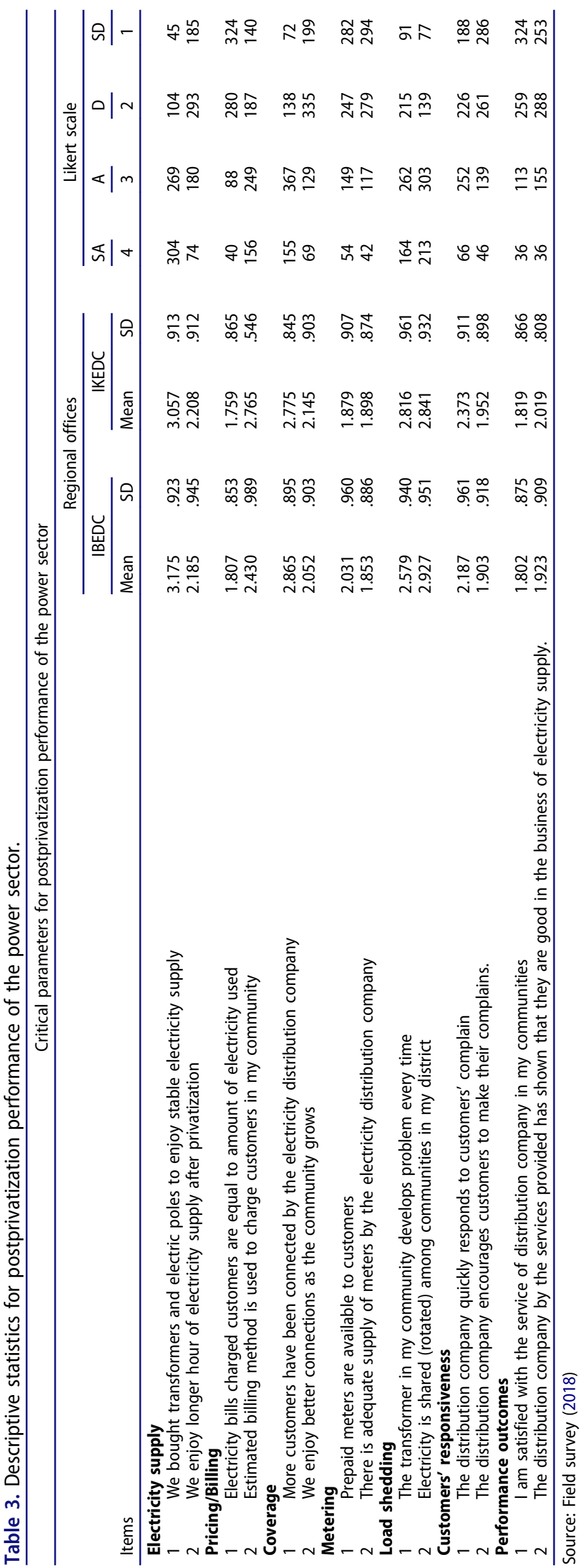


Table 4. Regression analysis between critical parameters measures and performance outcomes.

\begin{tabular}{lcccc}
\hline \multicolumn{4}{c}{ Model summary } \\
\hline Model & $\mathrm{R}$ & $\mathrm{R}$ square & Adjusted R square & Std. error of the estimate \\
\hline 1 & $.456^{\mathrm{a}}$ & .208 & .202 & .391012 \\
\hline aPredictors: & (Constant), & Customers_Responsiveness, & Load_Shedding, \\
Electricity_Supply, Pricing_Billing, Metering, Coverage & \\
Dependent: Performance Outcome \\
Source: Field Survey (2018)
\end{tabular}

Table 5. Analysis of variance (ANOVA).

\begin{tabular}{|c|c|c|c|c|c|c|}
\hline \multicolumn{7}{|c|}{ ANOVA } \\
\hline & del & Sum of squares & Df & Mean square & $\mathrm{F}$ & Sig. \\
\hline 1 & $\begin{array}{l}\text { Regression } \\
\text { Residual } \\
\text { Total }\end{array}$ & $\begin{array}{r}29.168 \\
110.845 \\
140.014\end{array}$ & $\begin{array}{r}6 \\
725 \\
731\end{array}$ & $\begin{array}{r}4.861 \\
.153\end{array}$ & 31.797 & $.000^{\mathrm{b}}$ \\
\hline
\end{tabular}

bredictors: (Constant), Customers_Responsiveness, Load_Shedding, Electricity_Supply, Pricing_Billing, Metering, Coverage

Source: Field Survey (2018)

Interpretation of result. Table 6 shows that $\mathrm{F}$ value is 31.797 at $.000 \mathrm{~b}$ significant level. This implies that critical parameters indicative of postprivatization success factors of the power sector have no significant effect on performance outcome of DISCOs with zero or negligible significant level.

Interpretation of result. The coefficient Table 6 shows the simple model that expresses the extent to which critical parameters of the power sector has an effect on performance outcome and which of the variables included in the model contributed to the prediction of the dependent variable. The tests of Tolerance showing individual values above 0.20 (Menard, 1995) and VIF with individual value below 10 (Myers, 1990) prove that there is no concern of multicollinearity problem. The study is interested in comparing the contribution of each independent variable; therefore, beta values are used for the comparison.

The model indicated that electricity supply had the most statistical significance in predicting performance, recording the highest beta value of $(b e t a=.256$, with

Table 6. Coefficients.

\begin{tabular}{|c|c|c|c|c|c|}
\hline \multicolumn{6}{|c|}{ Coefficients } \\
\hline \multirow[b]{2}{*}{ Model } & \multicolumn{2}{|c|}{$\begin{array}{c}\text { Unstandardized } \\
\text { coefficients }\end{array}$} & \multirow{2}{*}{$\begin{array}{c}\text { Standardized } \\
\text { coefficients } \\
\text { Beta }\end{array}$} & \multirow[b]{2}{*}{$\mathrm{T}$} & \multirow[b]{2}{*}{ Sig. } \\
\hline & B & $\begin{array}{l}\text { Std. } \\
\text { error }\end{array}$ & & & \\
\hline 1 (Constant) & 2.425 & .098 & & 24.702 & .000 \\
\hline Electricity_Supply & .256 & .073 & .400 & 11.241 & .000 \\
\hline Pricing_Billing & -.129 & .061 & .149 & 2.395 & .003 \\
\hline Coverage & .121 & .075 & .132 & 2.857 & .002 \\
\hline Metering & .177 & .060 & .138 & 3.875 & .000 \\
\hline Load_Shedding & .186 & .061 & .237 & 4.139 & .000 \\
\hline $\begin{array}{l}\text { Responsiveness to } \\
\text { Customer }\end{array}$ & .124 & .071 & .143 & 2.153 & .009 \\
\hline
\end{tabular}

Dependent Variable: performance outcome

Source: Field Survey (2018) a $T_{\text {val }}$ higher than 1.96, Sig. $.000 p<.05$ ), followed by customers' responsiveness with a beta value of ( beta $=.224$, $T_{\text {val }}$ higher than 1.96, Sig. .009 $p<.05$ ). Pricing/billing does made inverse significant contribution in explaining performance outcome, as it shows a negative beta value (beta $=-.129, T_{\text {val }}$ lower than $\left.1.96, p>.05\right)$. The regression equation from table 4.10 is:

\section{Performance outcome Predicted $=2.425+.129 *$

$$
\begin{aligned}
& \text { electricity }_{\text {supply }-.} .129 * \text { pricing/billing } \\
& +.121 * \text { coverage }+.177 * \text { metering } \\
& +.186 * \text { loadshedding }+.224 * \\
& \text { customers'responsiveness }
\end{aligned}
$$

By interpretation, it means that for every unit increase in electricity supply, a .129 unit increase in performance outcome is predicted, holding all other variables constant. On the other hand, for every unit increase in coverage, metering, load shedding and customers' responsiveness, there is $12.1 \%, 17.7 \%, 18.6 \%$, and $22.4 \%$ increase in performance outcome; while for every unit increase in the pricing/billing, we expect an approximately $12.9 \%$ decrease in performance outcomes. This means that electricity supply and customers' responsiveness makes the strongest unique contribution to explaining performance outcome.

Decision. The significance level below 0.05 implies a statistical confidence of above $95 \%$. This means that the critical parameters of the power sector have an effect on performance outcome. Thus, the null hypothesis $\left(\mathrm{H}_{0}\right)$ that states that "critical parameters have no significant impact on the postprivatization performance of the IBEDC and IKEDC in Nigeria" was accepted; while the alternative hypothesis $\left(\mathrm{H}_{1}\right)$ which says that the critical parameters have significant impact on the postprivatization performance of the IBEDC and IKEDC is rejected. This means that privatization of the power sector does not improve performance of both DISCOs judging by the parameters or variables of Responsiveness to customers, load shedding, supply, pricing, metering, and coverage.

\section{Discussion of findings}

Having carried out the descriptive and inferential statistical analysis via regression test, the research at this point reviews the implications of the findings for the DISCOs, customers and the country. The findings revealed that there is low performance of both DISCOs judging by the critical success factors outputs from the earlier series of analysis in section 5.0. This implies that IBEDC and IKEDC, as private firms operating in a liberalized market, have underperformed in providing services to the 
residential and commercial customers especially, on electricity supply, pricing/billing, and metering with great implications for businesses' thriving, that is suggesting that poor power supply would make commercial customers seek alternative sources (independent power generator) thereby incurring additional cost of operation with a dire effect on profit margin.

Also, the finding suggests that citizens' welfare promotion through stable power supply to enhance quality of living is undermined and the country's socioeconomic development is generally threatened. As such, the privatization theory argument of inherent performance capacity of private sector efficiency, productivity and efficient service by Muogbo (2013) is contrasted and this corresponds with the submission of Aluko (n.d.) that inflated contract, patronage and corruption are the sources of private firms profit in Nigeria and not inherent efficiency. Likewise, while the research finding strongly counterpoint the findings of Hashim (2017), Nepal and Foster (2016) Soukana and Anal (2015), it corroborates, to some extent, Pincus (2014) outcome on Cameroon, especially in the quality of service or electricity supply, pricing and overall impact on the economic growth. One can infer that close corresponding outcome of postprivatization performance of both Nigeria and Cameroon, as revealed in this research and the work of Pincus (2014) respectively, suggest that privatization of the power sector has a fundamental error or poor contextual issue(s) in its application and demands a revision for appropriate implementation in both countries and, perhaps, other African countries that share similar experience.

\section{Conclusion and recommendations}

This study examined IBEDC and IKEDC postprivatization performance using critical success indicators of electricity supply, load shedding, pricing metering response to customers, and coverage area. The findings revealed that IBEDC and IKEDC underperformed as a private firms aimed to transform the electricity power sector by bringing their technical, management and financial capacities to bear towards ensuring quality service delivery to costumers.

Arising from the above findings with its implications and conclusion, the study recommends that IBEDC and IKEDC should inject fund for the replacement or upgrade of dilapidated power equipments, provision of meters, especially, pre-paid type while government make the business environment convenient for healthy competition and regulation. Similarly, DISCOs should explore capital market opportunities for funding and improvement of service to customers.

\section{Funding}

This work was supported by the Covenant University.

\section{References}

Abdul, B. O. (1992). Establishing machinery for effective revenue collection in a commercialised National Electricity Power Authourity (NEPA). NEPA Review.

Adelaja, O. O. (2007). Theoretical and empirical issues in privatisation: A comparative study of the British and Nigerian experience. Journal of Social Science, 14(1), 25-43.

Clarke, T., \& Chisto, P. (1993). The political economy of privatisation. London and New York: Routledge.

Enoche, U. P., Egware, H. O., \& Eyakanor. (2015). TO. The Nigeria electric power sector (Opportunities and Challenges). Journal of Multidisciplinary Engineering Science and Technology (JMEST), 2(4), 494-502.

Fiel Survey (2018). Research Questionaire for Data Collection. Unpublished.

Gujral, A. (2013). Electricity distribution- buying a complex asset and transforming it into an efficiently run enterprise in a privatised power sector: The pain and the glory. (online) Retrieved from www.pwc.com/ng

Hashim, A. (2017). An assessment of electricity sector reforms in Iraq. (Online) Retrieved from www.bayancenter.org/en/ wp-content/uploads/2017/09/909865676600pdf

Ibadan Electricity Distribution Company (IBEDC). (2017). Customers information. IBEDC Prospectus Report.

Ibietan, J. (2013). New public management and public service effectiveness in Nigeria: A pragmatic discourse. Public Policy and Administration Research, 3(7), 53-61.

Ikeja Electricity Distribution Company (IKEDC). Customers' data and report. IKEDC Prospectus Report.

Israel, G.D. (2013). Determining Sample Size. Institute of Food and Agricultural Sciences (IFAS), University of Florida, PEOD -6, 1-5

Krejcie, R. V., \& Morgan, D. W. (1970). Determining sample size for research activities. Educational Journal and Psychological Measurement, 301, 607-610.

Menard, S. (1995). Applied Logistic Regression Analysis. Sage University Paper Series on Qualitative Applications in the Social Sciences, 07-106, Thousand Oaks, C.A: Sage

Muogbo, U. S. (2013). Impact of privatization on corporate performance: A study of selected industries in Nigeria. International Journal of Humanities and Social Science Invention, 2(7), 81-89.

Myers, R. H. (1990). Classical and modern regression with applications. Boston: PWS-Kent Publishing.

Nepal, R., \& Foster, J. (2016). Electricity networks in Australia: An overview of the debate. (Online) Retrieved from www.uq.edu.au/economic/abstract/54.pdf

Omoleke, I. I. (2011). Management of electricity generation and supply in Africa: The Nigerian experience. Journal of Public Administration and Policy Research, 3(10), 266-277.

Omoleke, I. I., \& Adesopo, A. A. (2005). Privatisation of Nigerian public enterprises: Its practical challenges as a reformulated policy of the fourth republic. African Journal of Public Administration, (2), 64-80.

Onagoruwa, B. (2011). Nigeira power sector reforms and privatisation. (Online) Retrieved from www.sec.gov.ng/files/Bolanle \%onagoruwa\%20presentation\%2060\%20DG5SECpdf 
Pincus, J. (2014). Public choice theory had negligible effect on Australian microeconomic policy, 1970s to 2000s. School of Economics, 2041 Working Paper No. 2014-02

Soukaina, A., \& Amal, E. (2015). The British privaisation of electricity network industry: The effect of the electricity reform on domestic electricity prices in the United Kingdom. (Online) Retrieved from users.unimi.it/eusers/ wp-content/uploads/Electricity-uk-A-El_Ghadfapdf

United Nations Conference on Trade and Development (UNCTAD). (2009). Investment policy review: Nigeria. Switzerland: United Nations publication. (Online) Retrieved from www.unctad.org/ipr
Urgorji, E. C. (1995). Privatisation/commercialization of stated-owned enterprises in Nigeria. Strategies for improving the performance of the economy. Comparative Political Studies, 24(4), 537-560. doi:10.1177/0010414095027004003

Zafar, A. (2015). Best Practices-India Power Sector Restructuring Study: Short Review of Privatisation in Power Sector. Retrieved on 15th November, 2017 from pdfusaid/pdf-docs/PAOOMPHQpdf.

Zayyad, H. R. (1992). Privatisation and commercialisation in Nigeria. (Online) Retrieved from www.unpan/un.org/infra doc/group/public/documents/AAPMAM/UNPAN 0282228pdfon 